\title{
ECONOMIC BEHAVIOR OF MICRO AND SMALL BUSINESS HOUSEHOLDS IN A BRANCHLESS BANKING SYSTEM
}

\author{
Ktut Silvanita Mangani $^{{ }^{*}}$, Yusman Syaukat ${ }^{2}$, Bustanul Arifin $^{3}$, and Mangara Tambunan ${ }^{4}$ \\ ${ }^{1}$ Department of Magister Management, Graduate School, Universitas Kristen Indonesia, \\ Jakarta, 10430, Indonesia \\ ${ }^{2,4}$ Department of Resource and Environmental Economics, FEM, Bogor Agricultural University, \\ Bogor, 16680, Indonesia \\ ${ }^{3}$ Department of Agribusiness, Faculty of Agriculture, Universitas Lampung, \\ Lampung, 35145, Indonesia
}

\begin{abstract}
Introduction: This study aims to analyze how the existence of branchless banking in rural areas affects the economic behavior of the micro and small business households, and vice versa. Background Problem: Within the framework at inclusive finance program, Indonesia has implemented the branchless banking model. However, the impact of the branchless banking system to micro and small business household has not discussed yet. Research Method: The research was conducted in Bogor District, with many remote villages adjacent to Jakarta, a capital city of Indonesia. A total of 97 samples of micro and small business households were selected from 13 sub-districts. The estimation was conducted using 2SLS method. The model describes the existing condition that explains the uniqueness of the economic behavior of the micro and small business households in a branchless banking system. Novelty: Studies related to branchless banking generally analyzed from the perspective of banking institutions. However, this study focusses on supply side, namely it analyze the household economic behavior using simultaneously equal model. Findings: The results show that the presence of branchless banking agents, as measured by the value of the transactions conducted by the households, have little effect on the economic behaviour of the micro and small business households. On the other hand, the economic behavior variables which are expected to affect the value of the transactions do not occur. The results explain that the utilization of the banking services provided through agents in the branchless banking system is in the form of payment transactions. In addition, the presence of branchless banking in rural areas has not affected production activities and vice versa. Conclusion: This study suggests a further study to find out the factors that make business actors unwilling to perform financial transactions related to their production activities through branchless banking agents.
\end{abstract}

ARTICLE INFO

Article history:

Received 20 December 2017

Received in revised form 6 December 2018

Accepted 19 January 2019

Keywords:

branchless banking, financial transaction, financial agent, economic behavior variable, transaction value

JEL Code:

D13, G20, J22, O12

\footnotetext{
* Corresponding Author at Department of Magister Management, Graduate School, Universitas Kristen Indonesia, Jalan Diponegoro No. 84-86, Jakarta 10430, Indonesia.

E-mail address: ktut.silvanita@uki.ac.id (author\#1), ysyaukat@gmail.com (author\#2), barifin@uwalumni.com (author\#3), mangara43tambunan@yahoo.com (author\#4)
} 


\section{INTRODUCTION}

World Bank survey data (2014) showed that only about $50 \%$ of the world's adult population has access to formal financial institutions. In countries such as Bangladesh, India and the Philippines, the percentage of adult residents who have access to formal institutions is $39.6 \%$, $35.2 \%$, and $26.6 \%$, respectively; while in Indonesia it is only about $19.6 \%$. The low percentage of the adult population who do not have access to formal financial institutions is partly due to the uneven distribution of the existence of these institutions. In general, the existence of these institutions is more concentrated in urban areas than in rural areas. Hisighsuren (2006) explained that the main factors that hamper formal financial institutions from entering rural areas are their wide geographical spread, low population density, and small transaction volume, resulting in high operational costs, and the large costs involved in building the physical office of the bank in a remote area. According to Kumar (2013) to reach a large share of disadvantaged and lowincome groups, it is necessary to deliver affordable banking services, as a banking sector initiative to cut across layers of society, regions, genders, and income as well as encourage the public to embrace banking habits. The results of the study by Firpo (2005) explain that for bank institutions to reach unbanked people, business processes and the implementation of new technologies are needed, as well as creative technology solutions to suit unique and often challenging needs in the emerging market and local context. McKay and Pickens (2010) explained that one form of a potential financial delivery channel to serve "unbanked" people, who mostly live in rural areas, is Branchless Banking (BB), i.e. a banking service provided by financial service providers to customers without having to come to the bank's offices. To that end, the bank uses a third party, or agent, as an extension of the bank's services in rural areas. Some observations found that branchless banking lowers the cost of banking services in remote areas, rather than opening conventional bank branches (Ivatury, 2008; Khattab, 2012; Jain, 2015).

The providers of branchless banking may come from a bank or non-bank institutions, such as telecommunications companies, or third parties that provide mobile payment services (mpayment). Several countries have implemented branchless banking with different models. Each model has strengths and weaknesses, as explained in Table 1.

Within the framework of inclusive financial programs, Indonesia implements the branchless banking model run by banking institutions. It is a relatively new financial delivery channel, or new banking technology, for low-income communities proclaimed in the National Strategy for Inclusive Finance, where banks bring their financial services closer to customers in remote areas.

In a branchless banking system, the bank may cooperate with a third party, called the Branchless Banking agent or BB agent, who acts as an extension of the bank and provides limited banking services to the surrounding area's customers. The agent's role is as an intermediary in cash transactions, such as digital cash exchanges or increasing savings balances, or otherwise converting money from digital forms into cash and withdrawing savings, as well as transferring and servicing online payment transaction services. The digital devices used may be magnetic stripe cards, such as credit cards and debit cards, smart cards, cell phones, computers, sales devices (Point Of Sales/POS) or Electronic Data Capture (EDC) that can read the user's data through the card, or other digital devices. The use of IT in BB is in line with The 
Table 1. Branchless Banking models: The Strengths and Weaknesses

\begin{tabular}{|c|c|c|c|}
\hline Who Leads & Strengths and Opportunities & Weaknesses and Threats & Examples \\
\hline $\begin{array}{l}\text { Mobile } \\
\text { operator }\end{array}$ & $\begin{array}{l}\text { - Comfort with transactional } \\
\text { revenue model; made possible } \\
\text { through mass-market approach } \\
\text { and aspiration of reaching every } \\
\text { last customer } \\
\text { - A large base of customers, many } \\
\text { unbanked } \\
\text { - A powerful distribution channel } \\
\text { (airtime resellers, own stores) } \\
\text { - Brand, reputation, solid finances } \\
\text { Need to drive revenue from new } \\
\text { services and customer loyalty. }\end{array}$ & $\begin{array}{l}\text { - Reluctant to increase the scope of } \\
\text { regulation (telco+banking) } \\
\text { - Unfamiliar with core banking } \\
\text { processes, reconciliations, exception } \\
\text { handling, fraud } \\
\text { - Reputational and financial risks larger } \\
\text { than telco billing } \\
\text { - Very concentrated sector-typically } \\
\text { 2-3 operators only }\end{array}$ & $\begin{array}{l}\text { M-PESA in Kenya } \\
\text { and Tanzania, } \\
\text { Smart Money and } \\
\text { G-Cash in the } \\
\text { Philippines, } \\
\text { Orange, Zain, and } \\
\text { MTN across Africa }\end{array}$ \\
\hline Bank & $\begin{array}{l}\text { - Banking license, subject to } \\
\text { supervision by banking } \\
\text { authorities } \\
\text { - Advance treasury, risk } \\
\text { management, and fraud } \\
\text { detection skills } \\
\text { Access to capital markets and } \\
\text { investment opportunities. }\end{array}$ & $\begin{array}{l}\text { - Revenue model typically based on the } \\
\text { float (interest rate) and product cross- } \\
\text { selling-present limited opportunities } \\
\text { for the poor } \\
\text { - The operate a costly infrastructure, } \\
\text { especially at the front end (branches) } \\
\text { but also in the back end (MIS) } \\
\text { Some customers are too expensive to } \\
\text { serve; little presence in the field } \\
\text { where poor people live }\end{array}$ & $\begin{array}{l}\text { Banking } \\
\text { correspondents in } \\
\text { Brazil, Chile, } \\
\text { Colombia, Peru }\end{array}$ \\
\hline $\begin{array}{l}\text { Third-party } \\
\text { m-payment } \\
\text { provider }\end{array}$ & $\begin{array}{l}\text { - Often coming from the } \\
\text { technology space } \\
\text { - More eager to drive } \\
\text { interoperability across banks } \\
\text { and telcos } \\
\text { Often eager to partner with } \\
\text { organizations serving the poor. }\end{array}$ & $\begin{array}{l}\text { They may not have much power over } \\
\text { much larger banks and telcos }\end{array}$ & $\begin{array}{l}\text { WIZZIT in South } \\
\text { Africa, Net U.E.P.S } \\
\text { in Africa, Eko in } \\
\text { India }\end{array}$ \\
\hline
\end{tabular}

Long Tail of Banking theory which is widely used to explain retail product offerings. Using the internet, retail companies can earn extra revenue by selling large quantities of small items in the skinny part of the tail. The theory suggested that IT has the potential to increase access to financial services for the population in a remote area (Weber, 2012).

A branchless banking system involves four major elements, namely service users, providers, agents, and digital devices. Services users (customers) are communities that are not served by banking facilities at all, called "unbanked people", as well as communities that have been served, but the facilities used are still limited, called "underbanked people" (Untoro et al.
2014). With the distribution of equitable financial services will create a source of new and rapid economic growth, thus creating more equitable growth Sanjaya (2014).

Bank Indonesia (BI) calls it "Layanan Keuangan Digital (LKD)" - the Digital Financial Services program, which aims not only to expand financial access but also increase technology-based economic activities (Untoro et al., 2014). BB program initiated by BI is linked to the implementation of national strategy called Financial Inclusion. The strategy aimed to promote economic growth by creating an equitable distribution of income in society, poverty alleviation and financial system stability (Bank Indonesia, 2014). BI believes that to achieve those objectives, financial institutions 
can play an important role through their intermediary function. According to this function, Financial Inclusion is efforts aimed at eliminating all forms of price and non-price barriers toward public access in utilizing financial services. Another institution that conducted a branchless banking program is "Otoritas Jasa Keuangan (OJK)" - the Financial Services Authority. OJK calls its program "Layanan Keuangan Tanpa Kantor Dalam Rangka Keuangan Inklusif" or "Laku Pandai" the Non-Office Financial Services in the Framework of Inclusive Finance. The aim of the program is to provide simple, easy-to-understand and appropriate financial products that meet the needs of people who have not been able to access the current financial services, and with the increasing number of members of different community groups in different parts of Indonesia using service finance, the economic activity of the community is expected to be more fluent so that it can encourage economic growth and equitable development among the regions in Indonesia, especially between villages and cities. The products offered are: (a) Savings with the characteristics of a Basic Saving Account (BSA). (b) Credit/Financing to Micro Business Actors. (c) Other financial products such as Micro Insurance (OJK, 2015).

So far, studies related to branchless banking, i.e. mobile banking or mobile money, have generally focused on the demand side, which analyzes the acceptance by society of the information technology used (Yuwono, 2017; Permadi, 2017; Chuchuen, 2016; Phanthanukitithaworn, et al., 2015; Montazemi, 2015). Research that has its focus on the supply side has generally analyzed matters from the perspective of the bank institutions as the providers in the BB program (Frani, 2017; Secioktaviany, 2016; Khanan, 2016; Wibowo, 2013). This study focuses on the supply side, namely it analyzes the household economic behavior using simultaneous equation models in the context of branchless banking.

The focus on household economics is based on Siregar (2009), who stated that national planning will provide benefits for the welfare of the community if the program could provide benefits for the households. Farm households became an important highlight in the studies, as they are the smallest unit that can describe the state of agricultural development. The welfare of farm households is an indicator of agricultural development's success. Therefore, this study aims to analyze the economic behavior of households, especially the households' micro and small businesses in rural areas, in terms of their production activities and financial transactions, and how the existence of branchless banking in the rural areas affects the economic behavior of the business households.

The results of this study may give information on the program's implementation, i.e. the economic behavior of the target group (micro and small businesses) in rural areas that have been involved in the BB program.

\section{RESEARCH METHODOLOGY}

\section{Characteristics of Household Business Activities in a Branchless Banking System}

The households referred to in the study were households residing in rural areas that have productive activities which produce goods and/or services, and they conduct their financial transactions through a BB agent who is based in the same area as the banks' customers. The micro and small business households' activities involved in the branchless banking program vary widely, such as stalls retailing staple goods, food stalls selling 'gado-gado' (local food: stewed vegetables with peanut sauce), noodles, meatballs, coffee, etc. Other kiosks sell mobile phones vouchers and electrical vouchers, eggs, toys, cakes, refills for drinking water containers, and many other different items. There are also 
businesses that provide services, such as photocopying services, barbers, beauty salons, motorcycle workshops, and money lenders.

The micro and small business households manage the use of the necessary production factors in their business activities and strive to meet their production targets, according to the production techniques they use. With the available financial (capital), the small entrepreneur (business actor) finances all of their production activities. Part of what they make is sold for income, while the rest goes for selfconsumption by the family (subsistence consumption). Revenues earned from these productive activities are allocated for expenditure on various family needs such as food and clothing, health and education expenses for their children, paying for electricity and other fixed obligations, and savings.

The micro and small business households conduct their financial transactions through BB agents, such as cash deposits (savings), cash withdrawals, money transfers, paying bills, and other financial transactions, such as buying cellphone top-up credit and electrical vouchers. In addition, the business actors may borrow funds from relatives, or banks through the BB agent, or borrow directly from a bank, or borrow from a money lender (loan shark).

\section{Specification of Household Economic Model}

Bagi and Singh (1974), with reference to microconditions in developing countries, stated that farm households were faced with problems in which one economic decision will depend on other economic decisions, both internal and external. Therefore, the household economic model of farmers is a dynamic model. The economic decisions of farm households are categorized into six decisions: production, consumption, marketed surplus, labor usage, investment, and credit.

In accordance with the characteristics of a branchless banking program, the decisions of a household involved in business include the decisions about their productive economic activities, household consumption decisions, and financial transaction decisions with the $\mathrm{BB}$ agent. The decisions on productive economic activities include output production decisions, input use decisions, and marketing decisions. The decisions on the use of inputs consist of capital use (investment), the use of labor, both family labor and outside the family workforce, and use of other raw materials. The households of the business actors have manpower that can be allocated to both household business activities and activities outside the household. The decision to sell the output in the market is based on the desired earnings and the fulfillment of the household's consumption needs. The decisions on household consumption include food and non-food consumption, as well as investment expenditure on human resources and health. Financial transaction decisions with the BB agent include cash deposits (savings), withdrawals, transfers, online bill payments and the payment of certain obligations, as well as obtaining credit from the bank that can be provided through the $\mathrm{BB}$ agent, or from the family or a money lender.

The decisions of a business household about its production activities, financial transactions, or other related household decisions are also influenced by the presence of a BB agent, as the spearhead of a branchless banking system. The presence of a BB agent in the midst of productive business activities is expected to boost production, by making their financial transactions easier and money available to the business. These conditions are expected to increase the output of the business, thus 
increasing the acceptance of, and creating more financial transactions for, the agent. Thus, the goal of a branchless banking program to reach "unbanked" and "underbanked" communities, create production growth, and expand the network/facilitation of strong financial services in the community, will be achieved.

In accordance with the characteristics of $\mathrm{BB}$ program, the decision of households involved in the business includes a decision on productive economic activities, household consumption decisions, and financial transaction decisions at the BB agents. Households economic decisions in the form of production decisions and consumption decisions, as well as the decision to take credit, and other decisions are influenced by the amount of household income received from various sources of income, formal and nonformal loans, as well as other factors such as household characteristics (Sayaka et al. 2011). Based on the field conditions related to the household production activities of micro and small businesses, a specification model for the research was developed. The model specification is based on the model of household economic decisions from Singh (1986), where production households maximize satisfaction within the constraints of income, time, and production technology:

$$
\mathrm{U}=u(\mathrm{Xa}, \mathrm{Xm}, \mathrm{Xl})
$$

Income constraint: $p m X m=p a(Q-X a)-w(L-F)$

Time constraint: $\mathrm{Xl}+\mathrm{F}=\mathrm{T}$

Technology constraint: $\mathrm{Q}=\mathrm{q}(\mathrm{L}, \mathrm{A})$

$\mathrm{U} \quad=$ Utility

$\mathrm{X}_{\mathrm{a}} \quad=$ Consumption of goods produced by the households

$\mathrm{X}_{\mathrm{m}}=$ Consumption of goods purchased in the market

$\mathrm{Xl}=$ Leisure Consumption

$\mathrm{p}_{\mathrm{m}} \quad=$ Prices of goods purchased in the market $\mathrm{p}_{\mathrm{a}}=$ The price of goods produced by the households

$\mathrm{Q}=$ Total production

$\left(\mathrm{Q}-\mathrm{X}_{\mathrm{a}}\right)=$ Surplus of production sold (marketed surplus)

$\mathrm{w} \quad=$ Wage rate

$\mathrm{L}=$ Total labor

$\mathrm{F} \quad=$ Input of family labor

A $\quad=$ Fixed assets

Furthermore, it generates a standard demand function:

$$
\mathrm{Xi}=\mathrm{Xi}\left(\mathrm{pm}, \mathrm{pa}, \mathrm{w}, \mathrm{Y}^{*}\right) \text {, in which } \mathrm{i}=\mathrm{m}, \mathrm{a}, 1
$$

Thus, it can be stated that the demand for goods is determined by the price of the output, the input prices, and income.

Model specifications of the production activities of a business household and its relation to its transaction activity in a branchless banking program are described in the following equations (note: the definition and types of variables are explained in Appendix 1):

$$
\begin{aligned}
\mathrm{Q}= & \mathrm{a}_{0}+\mathrm{a}_{1} \mathrm{INV}+\mathrm{a}_{2} \mathrm{TK}+\mathrm{a}_{3} \mathrm{P}+ \\
& \mathrm{a}_{4} \mathrm{VCOST}+\mathrm{a}_{5} \mathrm{TCONS}+\mu_{1} \\
\mathrm{INV}= & \mathrm{b}_{0}+\mathrm{b}_{1} \mathrm{Cr}+\mathrm{b}_{2} \mathrm{SAV}+\mathrm{b}_{3} \text { PFIT }+ \\
& \mathrm{b}_{4} \mathrm{FCOST}+\mu_{2} \\
\mathrm{TKK}= & \mathrm{c}_{0}+\mathrm{c}_{1} \mathrm{AKK}+\mathrm{c}_{2} \mathrm{~W}+\mathrm{c}_{3} \mathrm{TKL}+ \\
& \mathrm{c}_{4} \mathrm{PFIT}+\mu_{3} \\
\mathrm{TKL}= & \mathrm{d}_{0}+\mathrm{d}_{1} \mathrm{~W}+\mathrm{d}_{2} \mathrm{TKK}+\mathrm{d}_{3} \mathrm{P}+ \\
& \mathrm{d}_{4} \mathrm{MS}+\mu_{4} \\
\text { TK }= & \mathrm{TKK}+\mathrm{TKL} \\
\text { MS }= & \mathrm{e}_{0}+\mathrm{e}_{1} \mathrm{P}+\mathrm{e}_{2} \mathrm{Q}+\mathrm{e}_{3} \mathrm{SU}+\mu_{5} \\
\text { SU }= & \mathrm{f}_{0}+\mathrm{f}_{1} \mathrm{INV}+\mathrm{f}_{2} \mathrm{Cr}+\mu_{6} \\
\text { TRQ }= & \mathrm{Q}+0 \\
\text { PFIT }= & \text { TRQ }-(\mathrm{VCOST}+\mathrm{FCOST}) \\
\text { PRTBB = } & \text { PFIT }+ \text { PLL } \\
\text { YD = } & \text { PRTBB }-\mathrm{CS}-\mathrm{TAX}
\end{aligned}
$$




$$
\begin{aligned}
\mathrm{CC} \mathrm{PG}= & \mathrm{g}_{0}+\mathrm{g}_{1} \mathrm{YD}+\mathrm{g}_{2} \mathrm{UK}+\mathrm{g}_{3} \mathrm{SAV}+ \\
& \mathrm{g}_{4} \text { TRSNIL }+\mu_{7} \\
\mathrm{CCNPG}= & \mathrm{h}_{0}+\mathrm{h}_{1} \mathrm{YD}+\mathrm{h}_{2} \mathrm{CCPG}+\mathrm{h}_{3} \mathrm{SAV}+ \\
& \mathrm{h}_{4} \mathrm{ISDM}+\mathrm{h}_{5} \mathrm{TRSNIL}+\mu_{8} \\
\mathrm{TCONS}= & \mathrm{CCPG}+\mathrm{CCNPG} \\
\mathrm{ISDM}= & \mathrm{i}_{0}+\mathrm{i}_{1} \mathrm{YD}+\mathrm{i}_{2} \mathrm{AS}+\mathrm{i}_{3} \mathrm{SAV}+ \\
& \mathrm{i}_{4} \mathrm{INVPEN}+\mu_{9} \\
\mathrm{SAV}= & \mathrm{j}_{0}+\mathrm{j}_{1} \mathrm{PFIT}+\mathrm{j}_{2} \mathrm{YD}+\mathrm{j}_{3} \mathrm{TRSNIL}+ \\
& \mathrm{j}_{4} \mathrm{AS}+\mathrm{j}_{5} \mathrm{CCPG}+\mu_{10} \\
= & \mathrm{k}_{0}+\mathrm{k}_{1} \mathrm{R}+\mathrm{k}_{2} \mathrm{SU}+\mathrm{k}_{3} \mathrm{YD}+ \\
& \mathrm{k}_{4} \mathrm{PFIT}+\mathrm{k}_{5} \mathrm{INVPEN}+ \\
& \mathrm{k}_{6} \mathrm{TRSNIL}+\mu_{11} \\
\mathrm{TRSNIL}= & 1_{0}+\mathrm{l}_{1} \mathrm{PFIT}+\mathrm{l}_{2} \mathrm{YD}+\mathrm{l}_{3} \mathrm{SAV}+ \\
& \mu_{12}
\end{aligned}
$$

The expected sign of the parameters (hypothesis) of the equations are:

$a_{1}, a_{2}, a_{3}, a_{4}, a_{5} ; b_{1}, b_{2}, b_{3}, b_{4} ; c_{1}, c_{2}, c_{4} ; d_{3}, d_{4}$; $\mathrm{e}_{1}, \mathrm{e}_{2}, \mathrm{e}_{3} ; \mathrm{f}_{1}, \mathrm{f}_{2} ; \mathrm{g}_{1}, \mathrm{~g}_{2}, \mathrm{~g}_{4} ; \mathrm{h}_{1}, \mathrm{~h}_{3}, \mathrm{~h}_{4}, \mathrm{~h}_{5} ; \mathrm{i}_{1}, \mathrm{i}_{2}$,

$\mathrm{i}_{4} ; \mathrm{j}_{1}, \mathrm{j}_{2}, \mathrm{j}_{3}, \mathrm{j}_{4} ; \mathrm{k}_{2}, \mathrm{k}_{3}, \mathrm{k}_{4}, \mathrm{k}_{5}, \mathrm{k}_{6}, \mathrm{l}_{1}, \mathrm{l}_{2}, \mathrm{l}_{3}>0$, and $\mathrm{c}_{3}, \mathrm{~d}_{1}, \mathrm{~d}_{2}, \mathrm{~g}_{3}, \mathrm{~h}_{2}, \mathrm{i}_{3}, \mathrm{j}_{5}, \mathrm{k}_{1}<0$.

\section{Sampling Technique and Data Source}

The study was conducted with BRI bank, as one of the banks implementing the LKD and Lakupandai programs. The study was conducted in Bogor District, which has a large area and many remote villages. It is adjacent to Jakarta, the capital city of Indonesia. The data were collected during two months: November and December 2016.

Based on secondary data obtained from Bank BRI about the number of transactions conducted by agents, and based on the tasks and functions of the agents that are homogeneous, then 13 subdistricts out of the 40 sub-districts of Bogor District were selected purposively. The selected sub-districts have at least one active agent who conducts a high number of transactions, as one measure of the program's success. Furthermore, the selection of the agents was done purposively with the help of Bank BRI units in the selected sub-districts, and this resulted in 32 branchless banking agents being selected. The selection of the households' sample was also done purposively, i.e. the micro and small business households who have conducted financial transactions through an agent. For that purpose, the selection of micro and small business households was done with the help of the previously selected agents, and 97 households were obtained.

The instrument is designed, based on initial studies in the field, to know the production activities of the selected micro and small business households. Furthermore, the variables are determined based on the results of the discussion with the business actors and are based on the theory. This research uses cross-section data, obtained using an interview employing questionnaires that had been prepared.

The primary data are formed according to conditions in the field, using questionnaires, with interviews and observation techniques, as well as clarification between the respondents. The data collected are quantitative data, in accordance with the specifications of the model, which was formed based on theory and in accordance with the objectives of the study, and on the preliminary studies.

\section{Model Identification, Estimation, and Validation}

The model identification was performed using order criteria (Koutsoyiannis, 1977). If (K-M) $\geq$ (G-1), then the model is said to be identified or over-identified and therefore will result in a unique parameter. The model formulated in this study was a model of a simultaneous structural equation which has 18 equations, consisting of 12 structural equations and six identity equations. The sum of all variables in the model $(\mathrm{K})$ is 30 variables, consisting of 12 endogenous 
variables $(G)$ and 18 exogenous variables. The number of endogenous and exogenous variables included in one particular equation in the model (M) is seven variables. Since $(K-M) \geq(G-1)$, then the structural equations are said to be overidentified, thus the parameters can be estimated by using the 2SLS (Two Stage Least Squares) method (Gujarati, 1988).

Furthermore, the model is validated using Newton's method with the SIMLIN procedure to check whether the estimated models reflect reality and fulfill the requirements of the model application objectives (Sinaga, 2011). The criteria used are Root Mean Squares Percent Error (RMSPE) and U-Theil.

\section{RESULTS AND ANALYSIS}

\section{Characteristics and Transaction}

Activities Conducted by Micro and Small Business Households

The characteristics of micro and small business households include the average age of the households' member, length of formal education, family size (number of household members), number of labors who work in the micro and small business households, and number of school children in a household. It describes the performance or potential of the business household's activities. The average age (36.89 years) of the business actors involved in transactions with BB agents falls in the category of people considered to be of productive age, with the average level of education being equivalent to the third year of junior high school. The average family size is relatively small and consists of a husband, wife and two children. Of those amounts, more than half comprises the family's labor force, which means that their productive business activities are conducted by the father and mother, or by the father, mother, and at least one of their children. The charac- teristics of the micro and small business households are presented in Table 2 .

Table 2. Characteristics of business household

\begin{tabular}{lc}
\hline \multicolumn{1}{c}{ Characteristic } & Average \\
\hline Age (year) & 36.89 \\
Educational (year) & 9.82 \\
Family size (person) & 4 \\
Number of the family workforce & 3 \\
(person) & \\
Number of Schoolchildren (person) & 2 \\
\hline
\end{tabular}

Source: Own data

Most types of household business activities in rural areas involve running stalls; most of which sell basic daily necessities or staple goods. Other types of stalls are food stalls and other stalls selling different types of goods. Some other types of business household activities are business services, peddlers, and craftsmen. However, the distribution of each business activity is uneven, and the size of each business varies considerably, as described in Table 3.

Each of the micro and small business households generally has one or more business activities. However, this study focuses only on one business activity, i.e. their main business, whereas a second, or more, are calculated as additional income.

The micro and small business households' respondents are not classed as "unbanked people"-since they generally have bank accounts, although some were inactive. Some of them can be categorized as "underbanked people" because they have never used credit facilities from a bank. However, they tend to use cash $(69 \%)$ when conducting their transaction with the BB agent; only $31 \%$ respondents used an ATM, while the use of mobile phones for financial transactions (T-Bank) in a branchless banking program was not observed, as explained in Table 4. 
Table 3. Types of Business

\begin{tabular}{|c|c|c|c|}
\hline Types of business & Activity & $\begin{array}{l}\text { No. of } \\
\text { respondents }\end{array}$ & Percent \\
\hline Staple good stalls & Stalls sell: staple goods & 17 & 17.52 \\
\hline Food stalls & $\begin{array}{l}\text { Stalls sell: prepared food, 'gado-gado' (local food: stewed } \\
\text { vegetables with peanut sauce), 'bakso' (soup with } \\
\text { meatballs), coffee, noodles, fried chicken, etc }\end{array}$ & 12 & 12.37 \\
\hline Other stalls & $\begin{array}{l}\text { Stalls sell: drinking water refills, mobile phone \& } \\
\text { electrical vouchers, internet-game services, electrical } \\
\text { materials, paint, eggs, DVD, cakes, etc }\end{array}$ & 35 & 36.08 \\
\hline Services business & $\begin{array}{l}\text { Photocopying, motorcycle workshop, tailor, barber, beauty } \\
\text { salon, early childhood education programs, money lender, } \\
\text { etc }\end{array}$ & 21 & 21.65 \\
\hline Peddlers & $\begin{array}{l}\text { Peddlers selling bananas, crackers, 'putu' cake (traditional } \\
\text { cake),'siomay'(dumplings) }\end{array}$ & 7 & 7.22 \\
\hline Crafstman & Cobbler, wooden frame maker, fiberglass producer & 5 & 5.15 \\
\hline
\end{tabular}

Sources: Own data

Table 4. Instrument Used

\begin{tabular}{lcc}
\hline Instrument & No. of Respondent & Percent \\
\hline ATM & 30 & 31 \\
Cash & 87 & 69 \\
T-Bank & 0 & 0 \\
\hline Source. Own data
\end{tabular}

Source: Own data

The most common types of transactions used by the micro and small business households are those to pay bills, such as electricity payments $(45.59 \%)$, and transfer transactions $(27.13 \%)$. Transfer transactions are generally made by entrepreneurs who come from other regions; they send money to their families living in a different area. Other types of transfer transactions are transfers for online payments, such as payments for the purchase of goods online, and paying credit installments. Another type of transaction commonly undertaken by the micro and small business households with the BB agent is to buy cell phone vouchers (15.98\%), while transactions for making cash deposit (savings) and cash withdrawals are rare, as described in Table 5. The data show that the most frequent type of transaction, in general, is a transaction that is not related to business activities; while the type of transaction associated with production activities, and using the agent, such as depositing their daily or weekly income (savings transaction) or withdrawing funds for business needs (withdrawals transaction) are very rare.

Table 5. Frequency of Transaction

\begin{tabular}{lcc}
\hline \multicolumn{1}{c}{ Type of Transaction } & $\begin{array}{c}\text { Frequency/ } \\
\text { year }\end{array}$ & Percent \\
\hline Cash deposits & 187 & 6.46 \\
Withdrawals & 144 & 4.84 \\
Transfers & 576 & 27.13 \\
Electricity payment & & \\
(pre/post) & 1,346 & 45.59 \\
Buying mobile phone & & \\
vouchers & 422 & 15.98 \\
\hline Source: Own data & &
\end{tabular}

Table 5 also explains that the number of transactions conducted by micro and small business households through BB agents is low, with an average of 27.59 or 28 transactions per household per year or only two to three transactions per month.

\section{Estimation Results}

The estimation results are categorized into two components, namely the goodness of fit of the model and the predicted results. The goodness of 
fit of the model is shown by the test for variance (F-test), the coefficient of determination $\left(\mathrm{R}^{2}\right)$, and the partial test ( $\mathrm{t}$-test). The results show that all the F-test analyses were significant $(\operatorname{Pr} \mathrm{F}<$ 0.0001), which means that all the explanatory variables in each structural equation are simultaneously affecting each endogenous variable. The results of the determination of the coefficient $\left(\mathrm{R}^{2}\right)$ range from $27 \%-99.96 \%$, as shown in Table 6.

Next, to explain the magnitude of the influence of an explanatory variable on the endogenous variables, the elasticity value is used, which measures the percentage change in the explanatory variables to the percentage change in the endogenous variables in each equation. The use of the elasticity concept is considered more appropriate because the acquisition of the elasticity value comes from the estimated coefficient value of each explanatory variable. In other words, the elasticity value is the estimated value of the coefficient weighted on the average value of the explanatory variables and its endogenous variable.

\subsection{Production}

The estimation result of the production variable is presented in Table 7 .

Table 6. Analysis of Variance of Structural Equations of Household Economics Model, 2SLS method, and SYSLIN procedure

\begin{tabular}{llcccc}
\hline & Endogenous Variable & DF & F Value & Pr $>$ F & $\mathbf{R}^{2}$ \\
\hline Q & Production value & 96 & 164.58 & $<0.0001$ & 0.90042 \\
INV & Investment & 96 & $1,457.04$ & $<0.0001$ & 0.98766 \\
TKK & Family labor & 96 & 18.97 & $<0.0001$ & 0.45194 \\
TKL & Non-family labor & 96 & 11.33 & $<0.0001$ & 0.33003 \\
MS & Marketed surplus & 96 & $79,066.40$ & $<0.0001$ & 0.99961 \\
SU & Business size & 96 & 286.83 & $<0.0001$ & 0.85921 \\
CCPG & Food consumption & 96 & 44.31 & $<0.0001$ & 0.58834 \\
CCNPG & Non-food consumption & 96 & 27.21 & $<0.0001$ & 0.54192 \\
ISDM & HR investment & 96 & $25,684.10$ & $<0.0001$ & 0.99911 \\
SAV & Saving & 96 & 11.94 & $<0.0001$ & 0.27798 \\
CR & Credit & 96 & 27.72 & $<0.0001$ & 0.47209 \\
\hline
\end{tabular}

Table 7. Estimation result of production (Q) equation

\begin{tabular}{|c|c|c|c|}
\hline Variables & Parameters & Prob. $t^{x}$ & Elasticities \\
\hline INTERCEPT & $-1 . \mathrm{E}+07$ & & \\
\hline INV & 0.125983 & $0.0025^{*}$ & 0.02 \\
\hline $\mathrm{TK}$ & $21,717.42$ & $0.1259 * * *$ & 0.08 \\
\hline PS & $1.105 \mathrm{E}+10$ & $0.0079 *$ & 0.04 \\
\hline VCOST & 1.238950 & $<0.0001^{*}$ & 0.75 \\
\hline TCONS & 1.169064 & $0.1175^{* * *}$ & 0.10 \\
\hline \multicolumn{4}{|c|}{ 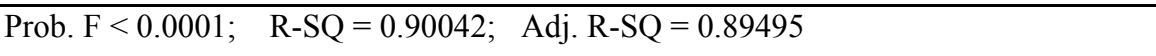 } \\
\hline
\end{tabular}


The production estimation results describe the behavior of households who earn an income from their businesses. The result of the determinant coefficient of $\mathrm{R}^{2}$ is $90 \%$, which means the variation in the endogenous variable (production) can be explained by the explanatory variables included in the equation. In the first specification of the model, it was stated that the production decisions for the micro and small business households were influenced by the output price (P). However, the estimation results indicate that the production of a business household in a branchless banking program is significantly affected by the shadow price (PS), which is the selling price of the output. By taking into account all the costs to produce an output, it is expressed by the ratio of the output's price to the production costs. This suggests that for rural micro and small business households, output prices are determined not only by market prices but also by taking into account all the production costs. This may be due to the businesses locations in the countryside, which can be relatively far from their input market, which is generally in an urban area, i.e. in the district or provincial capital.

Other explanatory variables which partially and significantly have an effect on the decisions of household producers are the investment variable (INV), variable cost (VCOST), total consumption expenditure (TCONS), and total labor usage (TK), as described in the production model below. The elasticity calculation shows that the response of the endogenous variable (production) to its influencing variables is inelastic $(e<1)$, which means that the variables have little effect on an increase in production by the business.

The consumption expenditure variable (TCONS) has a significant effect on production; however, the value of elasticity, $\mathrm{e}=0.1$ indicates that changes in family consumption expenditure have little impact on changes in production. The increase in household consumption only increases the production of the business by a small proportion. That is because not all households can use part of their production for consumption. The type of business that generally takes part in the production for family consumption is a stall selling staples goods. If available, households will take their consumption needs from their own stalls, such as cooking oil, eggs, noodles, and other items. While other types of businesses, such as stalls selling cellphone vouchers, motorcycle workshops, photocopying business, or other businesses, only use a small portion of the products they produce, since their products are not a daily necessity.

Out of the four explanatory variables that affect production, the variable cost (VCOST) has the highest elasticity $(e=0.75)$. This is in line with the characteristics of small businesses in rural areas, where any increase in production is more influenced by their variable input costs. This condition is understandable because business activities in rural areas are generally carried out in the house, where an increase in production is achieved by increasing the sales turnover, such micro and small as the addition of daily expenditures for their stalls. The result implies that credit for micro and small business households is primarily used to increase their sales turnover.

\subsection{Investment}

The result of the investment model is presented in Table 8 .

The investment equation model has been revised from the initial model. Credit and savings variables are not included in the model because they give an inconsistent sign to the theory. Credit variables (CR) which were predicted to affect investment, give insignificant 
results and the direction of influence is not in line with the hypothesis, so it is removed from the model. This is in line with the estimation and explanation of production decisions, that the credit required by a business household is primarily to increase its sales turnover, and not for investment. In addition, the conditions in the study area revealed that loans taken by the households, in general, were consumer loans, such as credit for motorcycle purchases, and other needs not related to business investment activities. The same thing happens with the savings variable (SAV) which is excluded from the model. Savings from micro and small business households in rural areas are usually unstructured and patternless. Savings are generally not intended for the business's development, but for family needs, such as for the children's schooling, savings for "haji", or to pay consumer credit installments.

Table 8. Estimation result of investment (INV) equation

\begin{tabular}{|c|c|c|c|}
\hline Variables & Parameters & Prob. $t^{x)}$ & Elasticities \\
\hline INTERCEPT & $-2.375 E+07$ & & \\
\hline PFIT & 0.005666 & 0.4600 & 0.01 \\
\hline FCOST & 10.00377 & $<0.0001^{*}$ & 1.07 \\
\hline UK & $4,842,465$ & $0.0744^{* *}$ & 0.40 \\
\hline TK & $7,269.944$ & $0.1219^{* * *}$ & 0.16 \\
\hline CCNPG & -0.40875 & $0.1388^{* * *}$ & -0.11 \\
\hline \multicolumn{4}{|c|}{$\begin{array}{r}\text { Prob. } \mathrm{F}<0.0001 ; \quad \mathrm{R}-\mathrm{SQ}=0 . \\
\text { Adj. } \mathrm{R}-\mathrm{SQ}=0.98699\end{array}$} \\
\hline
\end{tabular}

The size of the family (UK) variable, and total workforce (TK) were not predicted to affect investment, but the estimation result shows a significant effect. This is in accordance with the description of business activities in rural areas, which are generally carried out by family members. However, some types of businesses still require additional labor from outside the family, such as drinking water refill businesses, motorcycle workshops, and food stalls. Another variable previously thought to have no effect on investment, but actually has a significant and negative impact, is the non-food consumption variable (CCNPG). The increase in non-food consumption reduces business households' investment. It could also mean that an increase in investment can be made by reducing non-food consumption expenditure.

As predicted, the fixed cost variable (FCOST) is a variable that has a significant effect on investment and has the highest elasticity $(\mathrm{e}=1.07)$. The business profit variables (PFIT), although they have no significant effect on investment, do, however, provide the appropriate direction with the theory, and therefore are included in the model. This is possible because the estimation results in this study are not intended for prediction purposes, but only for simulation purposes.

\subsection{Family and Non-Family Labor}

The results of the estimation of family labor (TKK) and non-family labor (TKL) variables are presented in Table 9 and Table 10.

The estimation results show that the variables influence the use of family labor (TKK) and non-family labor (TKL) in accordance with the variables predicted in the model specification. Increased wages (W) do not significantly increase the use of family labor (TKK). This is due to the limited number of workers in a family, an average of four members per family. In general, those who work in the micro and small business households are the head of the family and/or his wife, while their children are still in school, or already working. On the other hand, an increase in wages (W) significantly decreases the use of external labor (TKL), with elasticity $\mathrm{e}=-0.28$. The profit (PFIT) variable is also not statistically significant, but the direction of the change is as 
expected in the hypothesis, and in line with the theoretical considerations.

Table 9. Estimation result of family labor (TKK) equation

\begin{tabular}{lccc}
\hline \multicolumn{1}{c}{ Variables } & Parameters & Prob. $^{\mathbf{x})}$ & Elasticities \\
\hline INTERCEPT & 245.9959 & & \\
W & $6.177 \mathrm{E}-06$ & 0.4037 & 0.01 \\
AKK & 170.9070 & $<0.0001^{*}$ & 0.57 \\
TKL & -0.13936 & $0.0030^{*}$ & -0.07 \\
PFIT & $5.007 \mathrm{E}-07$ & 0.4264 & 0.07 \\
\hline \multicolumn{4}{c}{ Prob. F < 0.0001; $\quad$ R-SQ $=0.45194 ;$} \\
Adj. R-SQ = 0.42811 \\
\hline Source: Orn compilation
\end{tabular}

Table 10. Estimation result of non-family labor (TKL) equation

\begin{tabular}{lccc}
\hline Variables & Parameters & ${\text { Prob. } \mathbf{t}^{\mathbf{x}}}$ & Elasticities \\
\hline INTERCEPT & 765.4539 & & \\
W & -0.00012 & $0.0972^{* *}$ & -0.28 \\
MS & $1.391 \mathrm{E}-06$ & $0.0019^{*}$ & 1.14 \\
TKK & -1.31868 & $0.0047^{*}$ & -2.77 \\
P & 0.003410 & $0.0008^{*}$ & 0.62 \\
\hline \multicolumn{4}{c}{ Prob. F < 0.0001; R-SQ $=0.33003 ;$} \\
Adj. R-SQ $=0.30091$ \\
\hline
\end{tabular}

Source: Own compilation

Marketed surplus (MS) and family labor (TKK) are elastic and have a large impact on the use of non-family labor, with values of elasticity of 1.14 and -2.77 , respectively. The use of nonfamily labor will increase with an increase in the marketed surplus. As predicted, there is a substitution between the use of family labor (TKK) and external labor (TKL); an increase in family labor will decrease the use of external labor. This is in accordance with the typical characteristics of businesses in rural areas, which rely mostly on family labor.

\subsection{Marketed Surplus}

The estimation of the marketed surplus variables is presented in Table 11.

The marketed surplus describes the economic behavior of the households in earning an income. Factors that are partially and statistically significant in influencing the decision to sell the products (MS) are the shadow price (PS) and production $(\mathrm{Q})$. However, only the production variable has a big impact on the marketed surplus, with a value of $\mathrm{e}=1.01$, which means all of the increase in the number of products will be sold to the market. This is in line with the facts in the study site, and although business activities in rural areas are carried out in people's homes, only a small portion of this production is used for their daily needs. That is because not all the businesses produce products that can be consumed or boredom with the consumption of their production, for example, those who sell food do not always eat the food they produce.

Table 11. Estimation result of marketed surplus (MS) equation

\begin{tabular}{|c|c|c|c|}
\hline Variables & Parameters & Prob. $t^{x)}$ & Elasticities \\
\hline INTERCEPT & -3996061 & & \\
\hline PS & $5.328 \mathrm{E}+08$ & $0.0174^{*}$ & 0.002 \\
\hline SU & 0.001500 & 0.2819 & 0.002 \\
\hline Q & 0.996693 & $<0.0001^{*}$ & 1.010 \\
\hline \multicolumn{4}{|c|}{$\begin{array}{c}\text { Prob. } \mathrm{F}<0.0001 ; \quad \mathrm{R}-\mathrm{SQ}=0.99961 ; \\
\text { Adj. } \mathrm{R}-\mathrm{SQ}=0.99960\end{array}$} \\
\hline
\end{tabular}

\subsection{Business Size}

The estimation of the business size variable is presented in Table 12.

Table 12. Estimation result of business size (SU) equation

\begin{tabular}{|c|c|c|c|}
\hline Variables & Parameters & Prob. $t^{x)}$ & Elasticities \\
\hline INTERCEPT & $1.096 \mathrm{E}+08$ & & \\
\hline INV & 1.077970 & $<0.0001^{*}$ & 0.15 \\
\hline $\mathrm{CR}$ & 1.302987 & $<0.0001^{*}$ & 0.16 \\
\hline \multicolumn{4}{|c|}{$\begin{array}{c}\text { Prob. } \mathrm{F}<0.0001 ; \quad \mathrm{R}-\mathrm{SQ}=0.85921 ; \\
\text { Adj. R-SQ }=0.85621\end{array}$} \\
\hline
\end{tabular}

The business size in this study is measured by adding the main investment that has been depreciated into the production value. The 
estimation result shows that the investment variables (INV) and credit (CR) partially and significantly affect a household's decisions in determining the size of its business (SU). However, changes to these two variables only have a small impact $(e<1)$. It also means that it needs huge investment and/or credit to increase a business's size in remote areas.

\subsection{Food Consumption Expenditure}

The result of the estimation of the food consumption expenditure variable is shown in Table 13.

Table 13. Estimation result of food consumption (CCPG) equation

\begin{tabular}{lccc}
\hline \multicolumn{1}{c}{ Variables } & Parameters & Prob. $^{\mathbf{x}}{ }^{\mathbf{n}}$ & Elasticities \\
\hline INTERCEPT & $7,292,784$ & & \\
PRTBB & 0.051134 & $<0.0001^{*}$ & 0.49 \\
AS & $2,208,236$ & $0.0015^{*}$ & 0.18 \\
SAV & -0.06036 & $0.0414^{*}$ & -0.13 \\
\hline \multicolumn{4}{c}{ Prob. F $<0.0001 ; \quad R-S Q=0.58834 ;$} \\
Adj. R-SQ $=0.57506$ \\
Source: Own compilation
\end{tabular}

The food consumption expenditure is obtained from the production business and from the market. Households buy food in the market because not all the products produced can be utilized for household food needs. The previously predicted family size (UK) variable, which influences food consumption expenditure, is not significant and gives a change of direction that is inconsistent with the theory. Conversely, the variable for the number of schoolchildren (AS), which was previously unpredicted, has a significant effect. It shows that households in rural areas pay more attention to food consumption for school children. The value of financial transactions (TRSNIL) conducted by micro and small business households through branchless banking agents, which was predicted to affect food consumption expenditure, does not have a significant effect and gives a sign that is not in line with the hypothesis. This shows that the financial transactions of the households with the BB agent are not closely related to their food consumption.

It is the total income of the households (PRTBB), which is derived from the profit of the business activities (PFIT) and other income (PLL) that statistically and significantly affects food consumption expenditure. This model differs from the initial model, where the income variable affecting food consumptions is disposable income (YD), i.e. household income after taxes that is available to be spent and/or saved. That makes sense because the households' food consumption expenditure in remote areas is crucial, compared to their obligations to pay taxes. The results also show that the savings variable (SAV) has a negative and significant effect on food consumption expenditure, which means an increase in household savings will reduce consumption expenditure.

\subsection{Non-Food Consumption Expenditure}

An estimate of the non-food consumption expenditure variables is presented in Table 14.

Table 14. Estimation result of non-food consumption (CCNPG) equation

\begin{tabular}{|c|c|c|c|}
\hline Variables & Parameters & Prob. $t^{x)}$ & Elasticities \\
\hline INTERCEPT & $9,361,068$ & & \\
\hline YD & 0.043407 & $0.0917^{* *}$ & 0.39 \\
\hline CCPG & -0.93268 & $0.0832^{* *}$ & -0.89 \\
\hline ISDM & 1.927497 & $<0.0001^{*}$ & 0.83 \\
\hline TRSNIL & 0.130314 & $0.1408^{* * *}$ & 0.09 \\
\hline \multicolumn{4}{|c|}{$\begin{array}{c}\text { Prob. } \mathrm{F}<0.0001 ; \quad \mathrm{R}-\mathrm{SQ}=0.54192 \\
\text { Adj. } \mathrm{R}-\mathrm{SQ}=0.52200\end{array}$} \\
\hline
\end{tabular}

Source: Own compilation

Generally, the non-food goods are purchased from the market. The estimation results show that the disposable income (YD), food consumption (CCPG), human resources investment (ISDM), and transaction value at a $\mathrm{BB}$ agent (TRSNIL) partially and significantly have an effect on the non-food consumption expenditure 
(CCNPG). However, those variables have low elasticity $(\mathrm{e}<1)$.

Those variables correspond to the predicted variables in the initial model, except the savings variable (SAV) is excluded because it is insignificant and provided a sign that was contrary to the hypothesis. In contrast, the food consumption expenditure variables are influenced by the total household income (PRTBB). The type of income which affects the non-food consumption expenditure is disposable income (YD). It shows that food consumption expenditure is a priority, compared to non-food consumption expenditure. It is also supported with the result where the variable of food consumption expenditure (CCPG) has a negative effect on non-food consumption expenditure, which means that an increase in food consumption lowers the nonfood consumption expenditure. It could also mean that if households increase their non-food consumption expenditure, such as their expenditure on cigarettes, cell phone credits, spending on clothing and other items, they should reduce their food consumption expenditure. Household expenditure on cigarettes and mobile phone credits are viewed as routine expenditure.

The estimation result shows that the value of transactions conducted by households with branchless banking agents (TRSNIL) has a positive effect on non-food consumption expenditure. This is in accordance with the conditions in the study area, where the transactions made by the households with the agents are mostly for activities related to non-food expenditure, such as paying electricity bills, purchasing mobile phone vouchers, or for the payment of other obligations online.

\subsection{Human Resources Investment Expenditure}

The estimation of human resource investment variable is as follow:
Table 15. Estimation result of human resource investment (ISDM) equation

\begin{tabular}{|c|c|c|c|}
\hline Variables & Parameters & Prob. $t^{x)}$ & Elasticities \\
\hline INTERCEPT & $492,573.8$ & & \\
\hline YD & 0.001133 & $0.0001^{*}$ & 0.02 \\
\hline AS & $234,093.3$ & $<0.0001^{*}$ & 0.04 \\
\hline SAV & -0.00562 & $0.0033^{*}$ & -0.03 \\
\hline INVPEN & 0.996940 & $<0.0001^{*}$ & 0.86 \\
\hline Prob. $\mathrm{F}$ & $\begin{array}{l}<0.0001 ; \\
\text { Adj. R-SQ }=\end{array}$ & $\begin{array}{l}\mathrm{R}-\mathrm{SQ}=0 . \\
=0,99907\end{array}$ & 99911; \\
\hline
\end{tabular}

Source: Own compilation

The human resource investment expenditure (ISDM) is part of the income used to finance education and health. The results show that the variables of disposable income (YD), the number of schoolchildren (AS), savings (SAV), and education investment (INVPEN) partially and significantly have an effect on the investment spending decisions for human resources. However, the elasticity value of all the variables affecting human resource investment is inelastic $(e<1)$, indicating that those variables have little impact on ISDM.

Educational investment (INVPEN) has the biggest impact, with an elasticity value of $\mathrm{e}=$ 0.86 . It could indicate that household expenditure for educational investment has a much larger share than health expenditure. The results of the interviews revealed that most of the respondents do not have health insurance, such as BPJS, so they do not have regular expenses for health payments. If they fall sick, they mostly use traditional medicines or medicine available in nearby stalls or go to the community health center (Puskesmas).

\subsection{Savings}

The estimation result of the saving variable is presented in Table 16.

The disposable income (YD) variable, the number of schoolchildren (US), and food consumption (CCPG) partially and significantly affect the saving variable. The disposable 
income (YD) and food consumption (CCPG) variables are elastic, with values of $\mathrm{e}=1.04$ and $\mathrm{e}=-2.02$, while the schoolchildren variable is inelastic $(e<1)$. This explains that households increase their savings from all their net income, and after fulfilling their tax obligations the increased disposable income will increase their savings.

Table 16. Estimation result of saving (SAV) equation

\begin{tabular}{|c|c|c|c|}
\hline Variables & Parameters & Prob. $t^{x)}$ & Elasticities \\
\hline INTERCEPT & $33,284,844$ & & \\
\hline YD & 0.227437 & $0.0338^{*}$ & 1.04 \\
\hline AS & $22,370,941$ & $<0.0001^{*}$ & 0.90 \\
\hline CCPG & -4.17823 & $0.0395^{*}$ & -2.02 \\
\hline \multicolumn{3}{|c|}{$\begin{array}{rc}\text { Prob. } \mathrm{F}<0.0001 ; & \mathrm{R}-\mathrm{SQ}=0 . \\
\text { Adj. R-SQ }=0.25469\end{array}$} & 27798 \\
\hline
\end{tabular}

The estimation result of the food consumption variable (CCPG) to savings (SAV) has a significant and negative effect. This suggests that there is "trade-off" between food consumption expenditure and savings, indicating that people in the study area are a low-income community, who, in contrast to high-income communities who can plan their savings early in the decision-making about their household income, their savings are determined by their spending on food consumption (Derosari, 2014).

The low coefficient of determination, $\mathrm{R}^{2}=$ 0.28 , indicates that there are other variables that influence saving. The low determination coefficient can be caused by the absence of any pattern in their savings. In addition, the form of their savings is not only in the form of money in their bank accounts but also in cooperative institutions, in addition to savings in the form of social gatherings ("arisan").

The estimation result explains that the transaction value (TRSNIL) conducted by the households with the BB agent has no significant effect on their savings (SAV) and produces a sign that is not in accordance with the hypothesis, so it is removed from the equation for the saving's model. This is in accordance with the conditions occurring in the research area, where transactions which occurred with the BB agent were more to do with non-food consumption expenditure and very few savings transaction activities.

\subsection{Credit}

The estimation result of the credit variable is presented in Table 17.

Table 17. Estimation result of credit (CR) equation

\begin{tabular}{|c|c|c|c|}
\hline Variables & Parameters & Prob. $t^{x)}$ & Elasticities \\
\hline INTERCEPT & $-5.868 \mathrm{E}+07$ & & \\
\hline SU & 0.147384 & $0.0338^{*}$ & 1.22 \\
\hline PFIT & 1.840791 & $<0.0001^{*}$ & 4.42 \\
\hline CCNPG & -4.92992 & $0.0569^{* *}$ & -1.53 \\
\hline INVPEN & 5.473640 & $0.0611^{* *}$ & 0.63 \\
\hline & $\begin{array}{l}<0.0001 ; \\
\text { Adj. R-SQ }\end{array}$ & $\begin{array}{l}\text { R-SQ }=0 . \\
=0.45368\end{array}$ & \\
\hline
\end{tabular}

Source: Own compilation

The equation shows that the variables affecting the micro and small business households credit involved in the branchless banking have undergone a re-specification from the initial model. The variable interest rate $(\mathrm{R})$, which previously was predicted to affect credit, does not have a significant effect and has a sign that is the opposite of what was expected by the theory, so it is not included in the model. Conditions in the study area show that respondents who have credit, either from banks, leasing companies, or from a money lender, in general, cannot explain how much interest is owed on the loan imposed on them. They can only explain the amount of credit taken and the installments paid, as well as the time period of the loan. This illustrates that the credit taken by households in the study area is based not only on the interest rate but also on the ability to pay and the time period of the installments. This is 
understandable because in general, they borrow for consumption purposes with a long repayment period.

Like the savings variable, the estimation results also explain that the transaction value (TRSNIL) performed by households with the BB agent has no significant effect on credit (CR) and produces a sign that is inconsistent with the hypothesis. This is in accordance with the conditions occurring in the research area; transactions that occur via the $\mathrm{BB}$ agent are mostly related to non-food consumption expenditure. There has been no transaction activity in the form of credit requests through the agents.

The business profit variable (PFIT) has a positive effect and has a big impact on the increase in the demand for credit (CR), with an elasticity value of $e=4.42$. It gives an idea of the increasing role played by business profits in the increase of credit transactions through branchless banking agents.

The estimation results also show that rural micro and small business households, concerned with their children's schooling, are willing to increase their demand for credit (CR) if necessary, for educational investment in their children (INVPEN). This is demonstrated by the positive effect of educational investment (INVPEN) on household credit (CR), with an elasticity value of $\mathrm{e}=0.63$.

\subsection{Transaction Value}

In the model specification, the transaction value was expected to be an endogenous variable affected by the profit variable (PFIT), disposable income (YD), and savings (SAV). However, the estimation results show that these variables are not significantly influential and provide directions of change that were not in line with the theory. These results illustrate that the production activities of the micro and small business households involved in branchless banking have not impacted on their transaction activity with the BB agent. The results are in accordance with the conditions in the field, where only about two to five business actors near the location of the agents were involved in transactions with the $\mathrm{BB}$ agents. Most people who transact via the $\mathrm{BB}$ agents were not business actors, but members of the general public, such as housewives or migrant workers, who make transactions for the payment of their electricity bills, or to buy cell phone credit, or send funds to their families living in different areas.

\section{DISCUSSION}

The model generated in this study provides an overview of the existing conditions and the uniqueness of the economic behavior of the micro and small business households involved in the BB system. The model explains that the production behavior of small trading businesses, such as stalls, is strongly influenced by their expenditure on raw materials (variable cost) with high elasticity. The results are in line with the study by Heatubun (2001), who stated that farm production is more influenced (with high elasticity) by the cost of the seeds (input variable). But the results are different from the study by Derosari (2014), who found that livestock breeding, i.e. cows is highly influenced by the amount of labor, rather than the input costs, because, in the business of livestock production, the expenditure for the labor costs is a considerable proportion of the overall costs.

The behavior of the investment variables that are influenced by the fixed costs variable with a high elasticity value illustrates that the business activities of the households involved in the BB program are relatively stagnant. This is indicated by the business space that generally joined with their homes which tend to be fixed or smaller 
with the increasing of family members (children and/or son- or daughter-in-law), as well as their customers in their environment which relatively constant. The result is in line with the study by Heatubun (2001) in which farm production is strongly affected by the scale of the business variables.

In addition, the result shows that investment behavior is negatively affected by non-food consumption expenditure, which is in line with the study by Derosari (2014), who found that the increase in non-food consumption expenditure lowers the expenditure for productive investment activities.

The transaction value (TRSNIL) conducted by the households through the BB agents has no significant effect on savings (SAV), therefore, it can be concluded that the BB program does not affect the savings activities of the micro and small business households in rural areas. The behavior of the savings variable is strongly influenced by disposable income, which is in line with Derosari (2014). In addition, the model shows a unique aspect of the business households involved in the BB program, in the form of the influence of the number of children on the savings variable. It implies that the BB program can be implemented through school children's savings programs. These findings provide an insight into the need for socialization to encourage people to save their funds in the form of savings in banks through their schoolage children, in addition to savings in the form of jewelry, "arisan", and savings at cooperative institutions.

The behavior of the credit variable is significantly affected (with high elasticity) by business profits and business size, in line with the study by Azriani (2008), who demonstrated that the amount of credit received by small business owners is significantly affected by the credit's interest rate and asset level variables.
The model also shows that the non-food consumption variable is the only variable that is affected by the value of the transactions through the BB program. On the other hand, the model that previously predicted the household economic behavior variables will affect the value of transactions in the BB program does not occur. It indicates that the production activities do not have yet a linkage with the value of the transactions conducted in the BB program. This condition is in line with the portrait of BB's implementation, in which the transactions conducted via the BB agents were dominated by payment transactions, i.e. transactions related to non-food expenditure, such as electricity payments, cell phone credit purchases, transferring funds to families, as well as payment transactions related to the purchase of goods online.

\section{CONCLUSION, LIMITATION AND RECOMMENDATION}

The model generated in this study provides an overview of the existing conditions and the uniqueness of the economic behavior of the micro and small business households involved in the branchless banking system. The model explains that the existence of branchless banking, which is measured by the value of the transactions conducted by households through an agent, does not significantly affect savings, investment, and credit, as the variables related to production activities and banking services. However, it has a significant effect on non-food consumption expenditure. This is consistent with the conditions in the field, where the types of transactions that many households do with the BB agent were not directly related to their business activities, but involve paying electricity bills, purchasing cell phone credit, and transferring money to their families. On the other hand, the value of the transactions which are expected to be affected by the household 
economic behavior, do not occur. Those results explain that the utilization of banking services provided through agents in the branchless banking system is still in the form of payment transactions. Other banking services are not yet being utilized. In addition, the presence of branchless banking in rural areas has not yet affected production activities and vice versa. Therefore, this study suggests a further study to find out the factors that make the business actors unwilling to perform transactions in relation to their production activities, besides the payment transactions, through branchless banking agents.

In order for the branchless banking program to succeed, the involvement of the micro and small business households that are mostly found in rural areas needs to be encouraged. Therefore, this study recommends that the government, as the owner of the program, and the banks, as the program's implementers, need to jointly carry out socialization and education to make clear the importance of financial transactions, in relation to production activities, to build a financial system which is expected to encourage increases to the people's welfare in rural areas.

Finally, this study has a limitation, which can provide an opportunity for future research. This study only analyzes the economic behavior of micro and small business households who have been involved in transactions with an agent in the branchless banking system. The research can be expanded by analyzing its potential for all the households near to the agents' locations, and by making a comparison between the two. In addition, for the development of the branchless banking program, the research can be continued by performing simulations by changing various scenarios for the relevant variables. Further research can also be done by analyzing the factors that inhibit business actors from conducting financial transactions via branchless banking agents.

\section{REFERENCES}

Azriani, Z., (2008). Peranan Bank Perkreditan Rakyat Binaan Bank Nagari terhadap kinerja usaha kecil di Sumatera Barat [master thesis]. Bogor (ID): Institut Pertanian Bogor.

Bagi, F.L., and I.J. Singh, I, (1974). A microeconomic model of farm decisions in LDC: A simultaneous equation approach. Economics and Sociology Occasional Paper No. 207. Department of Agricultural and Rural Sociology. The Ohio State University. Columbus, Ohio.

Bank Indonesia, (2014). Booklet keuangan inklusif bank Indonesia. Available at: http://www.bi.go.id/id/perbankan/keuangani nklusif/edukasi/Contents/Buku\%20Saku\%2 0Keuangan\%20Inklusif.pdf, accessed on September $25^{\text {th }}, 2015$.

Chuchuen, C., (2016). The perception of mobile banking adoption: The study of behavioral, security, and trust in Thailand. International Journal of Social Science and Humanity. 6(7):547.

Derosari, B.B., (2014). Pengaruh kredit dan bantuan modal pada perilaku ekonomi dan kesejahteraan rumahtangga tani di provinsi Nusa Tenggara Timur [The effect of credit and capital aid on the economic behavior and welfare of household household in East Nusa Tenggara province]. Unpublished Dissertation, Graduate School. Bogor: IPB.

Firpo, J., (2005). Banking the unbanked: Technology's role in delivering accessible financial services to the poor. SEMBA Consulting, Oakland, CA. available at: http://www.sevaksolutions. org/docs/ Banking\%20the\% 20Unbanked. Pdf.

Frani, O., (2017). Dampak branchless banking sebagai strategi inklusi keuangan terhadap tingkat kompetisi industri perbankan Indonesia. Jurnal Ilmiah Mahasiswa FEB Universitas Brawijaya 5(2):1-7.

Gujarati, D.N., (1988). Basic econometrics. Second Edition. McGraw-Hill Book Company, New York . 
Heatubun, A.B., (2001). Pemberdayaan dan kegiatan petani multikomoditi [Empowerment and activity of multi commodity farmers]. Unpublished Masters Thesis, Graduate School. Bogor: IPB.

Hishigsuren, G., (2006). Information and communication technology and microfinance: Options for Mongolia (No. 42). ADB Institute Discussion Papers.

Ivatury, G., and Mas, I., (2008). The early experience with branchless banking. Focus Note 46. Washington, D.C.: CGAP.

Jain, C.S., (2015). A study of banking sector's initiatives towards financial inclusion in India. Journal of Commerce and Management Thought, 6(1), 55.

Khanan, Pujiyono., (2016). Aspek yuridis keberadaan agen dalam model branchless banking di sistem perbankan Indonesia. Jurnal Privat Law IV (1):13-20.

Khattab, I., Balola, Y. and Eldabi, T., (2012). Factors influencing branchless banking for microfinance in Sudan: Theoretical perspectives and future directions. European, Mediterranean and Middle Eastern conference on information systems. Available at: http://www.iseing.org/emcis/emcis2012/EM CISWebsite/proceedings/154. pdf

Koutsoyiannis, A., (1977). Theory of Econometrics. Basingstoke (GB): Palgrave Macmillan Limited.

Kumar, N., (2013). Financial inclusion and its determinants: Evidence from India. Journal of Financial Economic Policy, 5(1), 4-19

Mas, I. (2009). The economics of branchless banking. Innovations: Technology, Governance, Globalization, 4(2), 57-75.

McKay, C. and Pickens, M., (2010). Branchless banking 2010: Who's served? At what price? What's next? (Vol. 66). CGAP Focus Note.

Montazemi AR, Qahri-Saremi H. 2015. Factors affecting adoption of online banking: A meta-analytic structural equation modeling study. Information \& Management 52(2):210-226.

Otoritas Jasa Keuangan, (2015). Laporan kinerja OJK 2015. Tersedia pada http://www.ojk.go.id/id/berita-dankegiatan/publikasi/Documents/Pages/lapora n-kinerja-ojk-2015/FA_Laporan kinerjaOJK2015rev070116_II.pdf, accessed on April 10 $0^{\text {th }}, 2016$.

Phanthanukitithaworn, C., Sellitto, C., and Fong, M., (2015). User intentions to adopt mobile payment services: A study of early adopters in Thailand. The Journal of Internet Banking and Commerce. 20(1):1-29.

Permadi, A.D., (2017). Persepsi masyarakat desa Pendem Berbah terhadap teknologi branchless banking. [mini thesis]. Yogyakarta (ID): Universitas Negeri Yogyakarta.

Sanjaya, I., (2014). Inklusi keuangan dan pertumbuhan inklusif sebagai strategi pengentasan kemiskinan di Indonesia [Inclusion of finance and inclusive growth as a poverty reduction strategy in Indonesia]. Unpublished Masters Thesis, Graduate School. Bogor: IPB.

Sayaka, B., K.K. Dewa, S. Herman, S.R. Rudy, Supriyati, and A. Askin., (2011). Peningkatan akses petani terhadap permodalan di daerah lahan marjinal [Increasing farmers access to capital in marginal land areas]. Unpublished Research Seminar Paper. Center for Socioeconomic and Agricultural Policy (PSEKP). Agency for Agricultural Research and Development, Ministry of Agriculture.

Secioktaviany, Z.A., (2016). Optimalisasi manajemen risiko sebagai upaya preventif risiko hukum pada bank penyelenggara branchless banking di Indonesia. Privat Law 4(2):87-93.

Sinaga, B.M., (2011). Metode Pengumpulan Data [Method of collecting data]. Agricultural Economics Study Program. Faculty of Economics and Management of Graduate School. Bogor: IPB. 
Singh, I., L. Squire, and J. Strauss, (1986). The basic model: theory, empirical results, and policy conclusions. Agricultural household models: Extensions, applications, and policy, 17-47. Baltimore: The Johns Hopkins University Press.

Siregar, H., (2009). Makro-Mikro Pembangunan [Macro-Micro of Development]. Collection of Papers and Essays. Bogor: Institut Pertanian Bogor Press.

Untoro, P.R. Widodo, W. Yuwana, K. Dewi, and R. Cristina, (2014). Layanan keuangan digital: Hambatan dan faktor-faktor penentu keberhasilan [Digital financial services: Constraints and critical success factors]. Working Paper. Bank Indonesia.

Weber, D.M., (2012). The impact of information and communication technology on intermediation, outreach, and decision rights in the microfinance industry. ProQuest LLC.
789 East Eisenhower Parkway, PO Box 1346, Ann Arbor, MI 48106.

Wibowo, P.P., (2013). Branchless banking setelah multilisence: ancaman atau kesempatan bagi perbankan nasional. Makalah Persyaratan Sekolah Staf Pimpinan Bank Indonesia (SESPIBI) Angkatan XXXI, Jakarta (ID): SESPIBI.

World Bank, (2014). Global financial development report 2014. http://econ.worldbank.org/WBSITE/EXTER NAL/EXTDEC/EXTGLOBALFINREPOR T/0,,contentMDK:23489619 pagePK:6416 8182 piPK:64168060 theSitePK:8816097, 00.html, accessed on June $25^{\text {th }}, 2015$.

Yuwono, M., (2017). Strategi penigkatan minat petani menggunakan produk dan jasa keuangan formal dalam rangka keuangan inklusif [dissertation] Bogor (ID): Institut Pertanian Bogor. 
Appendix 1. Definition, Types of Variables, and Types of Equation

\begin{tabular}{|c|c|c|c|}
\hline $\begin{array}{l}\text { Name of } \\
\text { Variable }\end{array}$ & $\begin{array}{l}\text { Definition of Variable } \\
\text { (value per year) }\end{array}$ & $\begin{array}{l}\text { Type of } \\
\text { Variable }\end{array}$ & $\begin{array}{c}\text { Type of } \\
\text { Equation }\end{array}$ \\
\hline Q & $\begin{array}{l}\text { Value of production of one of the main businesses of the } \\
\text { households (Rp) }\end{array}$ & Endogenous & Structural \\
\hline INV & Investment in the main business $(\mathrm{Rp})$ & Endogenous & Structural \\
\hline $\mathrm{P}$ & Average price of output (Rp/unit) & Exogenous & $*$ \\
\hline VCOST & Variabel cost: raw material costs (Rp) & Exogenous & * \\
\hline FCOST & $\begin{array}{l}\text { Fixed cost: the rental value of the place of business and the } \\
\text { depreciation value of fixed goods (Rp) }\end{array}$ & Exogenous & $*$ \\
\hline SU & $\begin{array}{l}\text { Business size: the value of production plus the value of the main } \\
\text { assets that have depreciated (Rp) }\end{array}$ & Endogenous & Structural \\
\hline SAV & Households saving (Rp) & Endogenous & Structural \\
\hline TKK & Family labor used in the main business (man days) & Endogenous & Structural \\
\hline TKL & Non-family labor used in the main business (man days) & Endogenous & Structural \\
\hline TK & Total labor used in the main business (man days) & Endogenous & Identity \\
\hline AKK & Family workforce (no. of persons) & Exogenous & $*$ \\
\hline $\mathrm{W}$ & Wage rate $(\mathrm{Rp} / \mathrm{month})$ & Exogenous & * \\
\hline MS & Marketed surplus: the value of production sold in the market (Rp) & Endogenous & Structural \\
\hline TRQ & Total revenue production $(\mathrm{Rp})$ & Endogenous & Identity \\
\hline PFIT & Profit of the business $(\mathrm{Rp})$ & Endogenous & Identity \\
\hline PLL & $\begin{array}{l}\text { Other income from another activity or another household } \\
\text { member's income (Rp) }\end{array}$ & Exogenous & $*$ \\
\hline PRTBB & Total household income (Rp) & Endogenous & Identity \\
\hline YD & Disposable income: income after tax (Rp) & Endogenous & Identity \\
\hline CS & $\begin{array}{l}\text { Subsistence consumption: the consumption value of the } \\
\text { production (Rp) }\end{array}$ & Exogenous & $*$ \\
\hline TAX & Tax and other fixed contributions (Rp) & Exogenous & * \\
\hline CCPG & Food consumption expenditure (Rp) & Endogenous & Structural \\
\hline CCNPG & Non-food consumption expenditure (Rp) & Endogenous & Structural \\
\hline TCONS & Total consumption expenditure $(\mathrm{Rp})$ & Endogenous & Identity \\
\hline ISDM & $\begin{array}{l}\text { Investment in human resources: education and health investment } \\
\text { (Rp) }\end{array}$ & Endogenous & Structural \\
\hline INVPEN & Investment in the education of the children (Rp) & Exogenous & * \\
\hline UK & Family size (no. of persons) & Exogenous & * \\
\hline AS & Number of school children (no. of persons) & Exogenous & * \\
\hline $\mathrm{Cr}$ & Credit: the total amount of credit taken by the household (Rp) & Endogenous & Structural \\
\hline $\mathrm{R}$ & Interest rate $(\% /$ year $)$ & & \\
\hline TRSNIL & $\begin{array}{l}\text { Total value of the transactions of the household via the BB agents } \\
\text { (Rp) }\end{array}$ & Endogenous & Structural \\
\hline
\end{tabular}

